\title{
Novosphingobium indicum sp. nov., a polycyclic aromatic hydrocarbon-degrading bacterium isolated from a deep-sea environment
}

\author{
Correspondence \\ Zongze Shao \\ shaozz@163.com \\ Tianling Zheng \\ wshwzh@jingxian.xmu.edu.cn
}

\author{
Jun Yuan, ${ }^{1,2} \dagger$ Qiliang Lai, ${ }^{2} \dagger$ Tianling Zheng ${ }^{1}$ and Zongze Shao ${ }^{2}$ \\ ${ }^{1}$ Key Laboratory of Ministry of Education for Coast and Wetland Ecosystem Research, School of \\ Life Sciences, Xiamen University, Xiamen 361005, PR China \\ ${ }^{2}$ Key Laboratory of Marine Biogenetic Resources, Third Institute of Oceanography, State Oceanic \\ Administration, Xiamen, PR China
}

\begin{abstract}
A novel polycyclic aromatic hydrocarbon (PAH)-degrading bacterium, strain $\mathrm{H}_{2} 5^{\top}$, which was isolated from deep-sea water of the Indian Ocean, was studied phenotypically, genotypically and phylogenetically. Strain $\mathrm{H}_{2} 5^{\top}$ can utilize several $\mathrm{PAHs}$ including phenanthrene and fluoranthene as sole carbon sources. The $16 \mathrm{~S}$ rRNA gene sequence of strain $\mathrm{H}_{2} 5^{\top}$ showed the highest similarity with that of Novosphingobium naphthalenivorans TUT562 ${ }^{\top}(96.3 \%)$, and showed lower similarities (92.1-96.0\%) with other members of the genus Novosphingobium. The major fatty acids of strain $\mathrm{H}_{2} 5^{\top}$ were $\mathrm{C}_{14: 0} 2-\mathrm{OH}(3.2 \%), \mathrm{C}_{16: 0}(13.6 \%), \mathrm{C}_{16: 1} \omega 7 c(5.2 \%), \mathrm{C}_{18: 0}$ $(13.4 \%)$ and $\mathrm{C}_{18: 1} \omega 7 c(57.0 \%)$, which accounted for $92.3 \%$ of the total fatty acids. It had ubiquinone 10 as the major respiratory quinone and spermidine as the major polyamine. All these characteristics were consistent with those of recognized Novosphingobium species. Results of DNA-DNA hybridization experiments and BOX-PCR fingerprint comparisons also indicate that strain $\mathrm{H}_{2} 5^{\top}$ represents a novel Novosphingobium species, for which the name Novosphingobium indicum sp. nov. is proposed. The type strain is $\mathrm{H}_{2} 5^{\top}\left(=\operatorname{MCCC} 1 \mathrm{A01080}{ }^{\top}=\mathrm{CGMCC}_{1.6784^{\top}}\right.$ $=$ LMG $24713^{T}$ ).
\end{abstract}

Polycyclic aromatic hydrocarbons (PAHs) are hazardous environmental contaminants (Edwards, 1983; Harvey, 1991; Suess, 1976). Because of their hydrophobicity, they are difficult to remove. However, micro-organisms play a dominant role in the degradation and elimination of these contaminants from the environment (Alemayehu et al., 2004). Many PAH-degrading bacteria have been isolated from marine environments, including species of Novosphingobium (Nohynek et al., 1996; Balkwill et al., 1997; Sohn et al., 2004; Liu et al., 2005; Cui \& Shao, 2006; Wang et al., 2008; Cui et al., 2008).

In this study, we focused on an active PAH-degrading bacterium named $\mathrm{H} 25^{\mathrm{T}}$, which was isolated from deep-sea water of the Indian Ocean (Yuan et al., 2008). Strain $\mathrm{H} 25^{\mathrm{T}}$ can degrade several aromatic hydrocarbons including

†These authors contributed equally to this work.

Abbreviation: $\mathrm{PAH}$, polycyclic aromatic hydrocarbon.

The GenBank/EMBL/DDBJ accession number for the 16S rRNA gene sequence of strain $\mathrm{H}_{2} 5^{\top}$ is EF549586.

A transmission electron micrograph of cells of strain $\mathrm{H}_{2} 5^{\top}$ and details of rep-PCR profiles, cellular fatty acid contents, API 20NE and API ZYM test results and susceptibility to antimicrobial agents of strain $\mathrm{H}_{2} 5^{\top}$ and related strains are available as supplementary material with the online version of this paper. biphenyl, naphthalene, acenaphthene, 2-methylnaphthalene, dibenzofuran, dibenzothiophene, 2,6-dimethylnaphthalene, 4-methyldibenzothiophene, phenanthrene, anthracene, chrysene and fluoranthene (Yuan et al., 2008). Sequence analysis of the $16 \mathrm{~S}$ rRNA gene strongly suggested that strain $\mathrm{H} 25^{\mathrm{T}}$ represents a novel species of the genus Novosphingobium. In order to classify strain $\mathrm{H} 25^{\mathrm{T}}$, further analyses were carried out, including DNA base composition and fatty acid composition, analyses of polyamines and quinones and DNA-DNA hybridization.

Deep-sea water was sampled from a depth of $4546 \mathrm{~m}$ below the surface, $200 \mathrm{~m}$ above the seabed, in December 2005 during cruise DY-105A of the R/V Da-Yang Yi-Hao, at site IR-CTD5 ( $16^{\circ} 59.9412^{\prime} \mathrm{N} 124^{\circ} 58.2958^{\prime}$ E) on the Southwest Indian Ridge. The water sample was used for enrichment with crude oil as the carbon and energy source. Enrichment of an oil-degrading consortium was conducted on board immediately after sampling. In the laboratory, about 2 months later, $1 \mathrm{ml}$ enriched culture was transferred into $100 \mathrm{ml}$ fresh medium containing $\left(\mathrm{l}^{-1}\right)$ $1.0 \mathrm{~g} \mathrm{NH}_{4} \mathrm{NO}_{3}, 0.5 \mathrm{~g} \mathrm{KH}_{2} \mathrm{PO}_{4}, 2.8 \mathrm{mg} \mathrm{FeSO}$. $7 \mathrm{H}_{2} \mathrm{O}$ and $10 \mathrm{ml}$ sterilized crude oil, prepared with aged deep-sea water, $\mathrm{pH}$ 7.5. After incubation for 3 weeks at $28{ }^{\circ} \mathrm{C}, 1 \mathrm{ml}$ culture broth was transferred repeatedly to the same medium for further enrichment. Three sequential transfers 
were performed at 2-week intervals. Bacteria including strain $\mathrm{H} 25^{\mathrm{T}}$ were isolated by the plate-screening method on 216L marine agar medium (per litre of sea water; $1.0 \mathrm{~g}$ sodium acetate, $10.0 \mathrm{~g}$ tryptone, $2.0 \mathrm{~g}$ yeast extract, $0.5 \mathrm{~g}$ sodium citrate, $0.2 \mathrm{~g} \mathrm{NH}_{4} \mathrm{NO}_{3}, \mathrm{pH}$ 7.5). For morphological and biochemical characterization, strain $\mathrm{H} 25^{\mathrm{T}}$ was also cultivated on $216 \mathrm{~L}$ medium.

Genomic DNA was prepared according to Ausubel et al. (1995) and the 16S rRNA gene was amplified by PCR using primers described previously (Liu \& Shao, 2005). Sequences of related strains were obtained from the GenBank database. Phylogenetic analysis was performed by using DNAMAN (version 5.1; Lynnon Biosoft). Distances (distance options according to Kimura's two-parameter model) and clustering with the neighbour-joining (Saitou \& Nei, 1987) and minimum-evolution (Rzhetsky \& Nei, 1992, 1993) methods were determined by using bootstrap values based on 1000 replications. A tree constructed using the neighbour-joining method is shown in Fig. 1.

A nearly full-length $16 \mathrm{~S}$ rRNA gene sequence (1453 nt) of strain $\mathrm{H} 25^{\mathrm{T}}$ was determined. Phylogenetic analysis of strain $\mathrm{H} 25^{\mathrm{T}}$ indicated that it belonged to the Alphaproteobacteria, forming a robust clade with the genus Novosphingobium. As shown in Fig. 1, the closest related strains included Novosphingobium naphthalenivorans TUT562 ${ }^{\mathrm{T}}(96.3 \% 16 \mathrm{~S}$ rRNA gene sequence similarity), Novosphingobium pentaromativorans US6- ${ }^{\mathrm{T}}$ (96.0\%), Novosphingobium subarcticum $\mathrm{KF}^{\mathrm{T}}(95.8 \%)$ and Novosphingobium resinovorum NCIMB $8767^{\mathrm{T}}$ (95.8\%); other strains shared sequence similarities below $94.7 \%$. The name Novosphingobium resinovorum was created by the reclassification of
Flavobacterium resinovorum Delaporte and Daste 1956, with Novosphingobium subarcticum (Nohynek et al. 1996) Takeuchi et al. 2001 as a later heterotypic synonym (Lim et al., 2007). Alignment of the $16 \mathrm{~S}$ rRNA gene sequence of strain $\mathrm{H} 25^{\mathrm{T}}$ with those of members of the genus Novosphingobium confirmed the presence of the Novosphingobium signature nucleotides (52C, 134G, 359G, 593U, 987G, 990U, 1215A and 1218C; Takeuchi et al., 2001) in strain $\mathrm{H} 25^{\mathrm{T}}$. Although strain $\mathrm{H} 25^{\mathrm{T}}$ showed high $16 \mathrm{~S}$ rRNA gene sequence similarity to Altererythrobacter epoxidivorans $\mathrm{JCS} 350^{\mathrm{T}}(95.8 \%)$, they formed two different clades in the phylogenetic tree based on 16S rRNA gene sequences (Fig. 1). In general, a $16 \mathrm{~S}$ rRNA gene sequence divergence greater than $2 \%$ is accepted as a criterion for delineating different species (Stackebrandt \& Goebel, 1994). The 16S rRNA gene sequence divergence between strain $\mathrm{H} 25^{\mathrm{T}}$ and the closest type strain $N$. naphthalenivorans ${\text { TUT } 562^{\mathrm{T}}}$ was $3.8 \%$; the data therefore support the view that strain $\mathrm{H} 25^{\mathrm{T}}$ represents a novel species in the genus Novosphingobium.

DNA-DNA hybridization experiments were performed with genomic DNA from strain $\mathrm{H} 25^{\mathrm{T}}$, N. naphthalenivorans DSM $18518^{\mathrm{T}}$ and $N$. pentaromativorans US6- $1^{\mathrm{T}}$ using a previously described method (Liu \& Shao, 2005). Genomic DNA from Escherichia coli DH5 $\alpha$ was used as a reference sample, and salmon sperm DNA was used as a negative control. Strain $\mathrm{H}_{2} 5^{\mathrm{T}}$ showed low DNA-DNA relatedness of 31 and $38 \%$ to $N$. naphthalenivorans DSM $18518^{\mathrm{T}}$ and $N$. pentaromativorans US6- $1^{\mathrm{T}}$. This demonstrates their affiliation to different species in accordance with the cut-off value of $70 \%$ recognized by Wayne et al. (1987) for

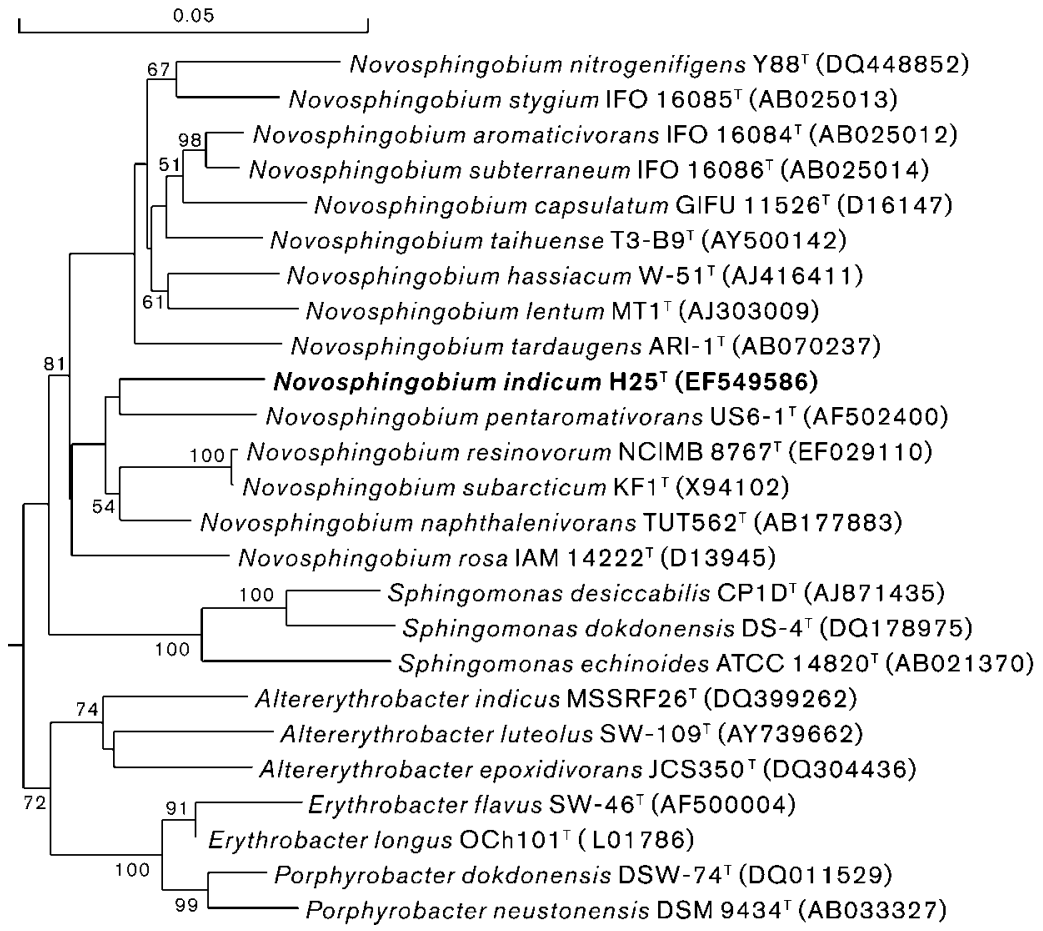

Fig. 1. Neighbour-joining tree showing the phylogenetic positions of strain $\mathrm{H}_{2} 5^{\top}$ and representatives of some other related taxa, based on 16S rRNA gene sequences. Bootstrap values (expressed as percentages of 1000 replications) are shown at branch points. Bar, 0.05 nucleotide substitution rate $\left(K_{\text {nuc }}\right)$ units. 
discrimination of bacterial species. Strain $\mathrm{H}_{25} 5^{\mathrm{T}}, N$. naphthalenivorans DSM $18518^{\mathrm{T}}, \quad$ N. pentaromativorans US6- $1^{\mathrm{T}}$ and $N$. subarcticum $\mathrm{KF} 1^{\mathrm{T}}$ were further compared by rep-PCR. In this study, the primer BOX-A1R (5'CTACGGCAAGGCGACGCTGACG-3') was used for repPCR fingerprint analysis (Versalovic et al., 1991). The PCR was carried out with the following cycle conditions: $5 \mathrm{~min}$ denaturation at $94{ }^{\circ} \mathrm{C}$ followed by 35 cycles of $15 \mathrm{~s}$ at $94{ }^{\circ} \mathrm{C}, 30 \mathrm{~s}$ at $53{ }^{\circ} \mathrm{C}$ and $8 \mathrm{~min}$ at $65^{\circ} \mathrm{C}$ and a final extension at $65{ }^{\circ} \mathrm{C}$ for $8 \mathrm{~min}$. The PCR products were separated by agarose $(2 \%)$ gel electrophoresis. The repPCR results are shown in Supplementary Fig. S1, available in IJSEM Online. Strain $\mathrm{H} 25^{\mathrm{T}}$ yielded a unique BOX-PCR fingerprint compared with related strains. These results confirm the result of DNA-DNA hybridization.

General cell morphology was observed under an Olympus inverted microscope using a 1-day-old culture grown on 216L agar. For electron microscopy, exponential-phase cells were harvested, resuspended and absorbed on a Formvar-carbon-coated grid and then stained with phosphotungstic acid. The Gram reaction, catalase and oxidase activities, lipase (Tween 80 hydrolysis), gelatinase and hydrolysis of aesculin were examined according to standard methods (Dong \& Cai, 2001). The optimal growth temperature was determined over the temperature range $4-45{ }^{\circ} \mathrm{C}$ on $216 \mathrm{~L}$ agar. The major respiratory quinone was determined by HPLC analysis according to Collins (1985). Polyamines were extracted and analysed according to Busse \& Auling (1988) and Busse et al. (1997). Other biochemical tests were carried out using API 20NE and API ZYM strips (bioMérieux) and the Biolog GN2 MicroPlate panel according to the manufacturers' instructions, with the $\mathrm{NaCl}$ concentration adjusted to $3.0 \%$. These results are given in the species description, Table 1 and Supplementary Table S1.

Fatty acids of cells grown aerobically in $216 \mathrm{~L}$ broth at $28{ }^{\circ} \mathrm{C}$ for $48 \mathrm{~h}$ were extracted, freeze-dried, saponified and esterified according to the methods described by Mrozik et al. (2004). Analysis of fatty acid methyl esters was performed on a GC-MS (Shimadzu model QP2010) equipped with an RTX-5MS column. As shown in Supplementary Table S2, the major fatty acids of strain $\mathrm{H}_{25} 5^{\mathrm{T}}$ were $\mathrm{C}_{14: 0} 2-\mathrm{OH}(3.2 \%), \mathrm{C}_{16: 0}(13.6 \%), \mathrm{C}_{16: 1} \omega 7 c$ $(5.2 \%), \mathrm{C}_{18: 0}(13.4 \%)$ and $\mathrm{C}_{18: 1} \omega 7 c(57.0 \%)$, which accounted for $92.3 \%$ of the total fatty acids; this profile is consistent with those of recognized Novosphingobium

Table 1. Physiological characteristics of strain $\mathrm{H}_{2} 5^{\top}$ and type strains of related Novosphingobium species

Strains: 1, strain $\mathrm{H}^{2} 5^{\mathrm{T}} ; 2$, N. naphthalenivorans DSM $18518^{\mathrm{T}} ; 3$, N. pentaromativorans US6-1 $1^{\mathrm{T}} ; 4$, N. aromaticivorans SMCC F199 $;$, 5 , capsulatum DSM $30196^{\mathrm{T}} ; 6$, N. rosa DSM $7285^{\mathrm{T}} ; 7$, N. stygium SMCC B0712 $; 8$, N. subarcticum $\mathrm{KF}^{\mathrm{T}}{ }^{\mathrm{T}} ; 9$, N. subterraneum SMCC B0478 ${ }^{\mathrm{T}} ; 10$, N. hassiacum DSM $14552^{\mathrm{T}} ; 11$, N. tardaugens JCM $11434^{\mathrm{T}}$; 12 , N. lentum DSM $13663^{\mathrm{T}} ; 13$, N. taihuense T3-B9 ${ }^{\mathrm{T}} ; 14, N$. nitrogenifigens $\mathrm{Y} 88^{\mathrm{T}}$. Data for reference strains were taken from Sohn et al. (2004), Tiirola et al. (2005), Liu et al. (2005), Suzuki \& Hiraishi (2007), Addison et al. (2007) and Lim et al. (2007). +, Positive; -, negative; $\mathrm{W}$, weakly positive; ND, no data available. All strains were positive for catalase and negative for arginine dihydrolase, indole production, denitrification and assimilation of citrate, D-mannitol and L-phenylalanine.

\begin{tabular}{|c|c|c|c|c|c|c|c|c|c|c|c|c|c|c|}
\hline Characteristic & 1 & 2 & 3 & 4 & 5 & 6 & 7 & 8 & 9 & 10 & 11 & 12 & 13 & 14 \\
\hline Oxidase & - & + & - & - & - & - & - & - & - & + & - & - & - & - \\
\hline Urease & - & - & - & - & - & - & - & - & - & - & - & - & - & + \\
\hline$\beta$-Galactosidase & - & - & - & + & + & + & + & + & + & - & - & - & $\mathrm{ND}$ & - \\
\hline Gelatin hydrolysis & + & - & - & - & + & - & - & - & + & - & - & - & - & - \\
\hline Aesculin hydrolysis & - & + & + & + & + & $\mathrm{w}$ & + & + & + & - & ND & - & + & $\mathrm{ND}$ \\
\hline Nitrate reduction & + & + & + & + & + & + & - & + & + & - & - & + & + & + \\
\hline \multicolumn{15}{|l|}{ Assimilation of: } \\
\hline$N$-Acetyl-D-glucosamine & - & - & - & + & + & $\mathrm{w}$ & - & + & - & - & - & - & - & + \\
\hline L-Arabinose & - & + & - & - & $\mathrm{w}$ & + & _- & + & w & - & _- & _- & + & _- \\
\hline L-Alanine & + & $\mathrm{ND}$ & - & - & - & - & - & - & - & - & - & - & - & - \\
\hline Cellobiose & - & $\mathrm{ND}$ & - & + & + & + & - & - & + & + & - & - & + & + \\
\hline D-Galactose & - & $\mathrm{ND}$ & - & - & + & - & - & + & - & - & - & - & - & + \\
\hline D-Glucose & + & + & - & + & + & + & - & + & + & + & - & - & + & + \\
\hline D-Fructose & - & ND & + & - & - & + & - & - & - & + & - & _- & + & + \\
\hline D-Mannose & + & - & - & + & w & + & - & - & + & - & - & - & + & + \\
\hline Maltose & + & + & _- & + & + & + & _- & + & + & - & _- & _- & + & + \\
\hline Melibiose & - & $\mathrm{ND}$ & - & - & - & + & - & - & + & - & - & - & - & - \\
\hline L-Rhamnose & - & ND & + & + & + & + & - & + & + & - & - & - & + & _ \\
\hline Sucrose & - & $\mathrm{ND}$ & + & + & + & + & - & - & + & + & - & - & + & + \\
\hline L-Proline & + & $\mathrm{ND}$ & + & + & - & - & - & + & + & + & - & - & + & - \\
\hline Trehalose & - & ND & + & - & + & - & - & - & - & - & - & _- & - & + \\
\hline $\mathrm{G}+\mathrm{C}$ content $(\mathrm{mol} \%)$ & 62 & 64.6 & 61.1 & 64 & 63 & 65 & 65 & 66 & 60 & ND & 61 & 66 & 63.3 & $\mathrm{ND}$ \\
\hline
\end{tabular}


species. Strain $\mathrm{H} 25^{\mathrm{T}}$, N. naphthalenivorans DSM $18518^{\mathrm{T}}$ and $N$. pentaromativorans US6- $1^{\mathrm{T}}$ contained similar proportions of $\mathrm{C}_{18: 1} \omega 7 c(57.0-64.0 \%)$ and $\mathrm{C}_{16: 1} \omega 7 c$ (5.2-8.8\%), but they differed significantly in the content of $\mathrm{C}_{14: 0} 2-\mathrm{OH}(3.2-19.7 \%)$ and $\mathrm{C}_{16: 0}(1-13.6 \%)$.

The $\mathrm{G}+\mathrm{C}$ content of the chromosomal DNA was determined according to the method described by Mesbah \& Whitman (1989) using reversed-phase HPLC. The $\mathrm{G}+\mathrm{C}$ content of strain $\mathrm{H} 25^{\mathrm{T}}$ was $62 \mathrm{~mol} \%$, which is within the range described for the genus Novosphingobium (60-66 mol\%).

Antibiotic susceptibility tests were performed by the discdiffusion method as described by Shieh et al. (2003). Strain $\mathrm{H} 25^{\mathrm{T}}, N$. naphthalenivorans DSM $18518^{\mathrm{T}}, N$. pentaromativorans US6- $1^{\mathrm{T}}$ and $N$. subarcticum $\mathrm{KF}^{\mathrm{T}}$ were tested at the same time in this study. All of them were sensitive to (per disc; Oxoid) ampicillin $(10 \mu \mathrm{g})$, carbenicillin $(100 \mu \mathrm{g})$, cefobid $(30 \mu \mathrm{g})$, chloromycetin $(30 \mu \mathrm{g})$, co-trimoxazole $(25 \mu \mathrm{g})$, erythromycin $(15 \mu \mathrm{g})$, gentamicin $(10 \mu \mathrm{g})$, kanamycin $(30 \mu \mathrm{g})$, minomycin $(30 \mu \mathrm{g})$, neomycin $(10 \mu \mathrm{g})$, penicillin $\mathrm{G}(10 \mu \mathrm{g})$, piperacillin $(100 \mu \mathrm{g})$, rifampicin $(5 \mu \mathrm{g})$ and rocephin $(30 \mu \mathrm{g})$, but resistant to lincomycin $(2 \mu \mathrm{g})$, metronidazole $(5 \mu \mathrm{g})$, oxacillin $(1 \mu \mathrm{g})$ and streptomycin $(10 \mu \mathrm{g})$. Differential susceptibility of the four strains to 12 other antibiotics is detailed in Supplementary Table S3.

Cells of strain $\mathrm{H} 25^{\mathrm{T}}$ were Gram-negative, yellow-pigmented rods without polar flagella (Supplementary Fig. S2). Strain $\mathrm{H} 25^{\mathrm{T}}$ had $\mathrm{C}_{14: 0}$ 2-OH as the major 2-hydroxy fatty acid and displayed nitrate reductase activity, ubiquinone 10 as the major respiratory quinone and spermidine as the major polyamine. These characteristics supported the phylogenetic evidence that strain $\mathrm{H} 25^{\mathrm{T}}$ belongs to the genus Novosphingobium. Differences in physiological, biochemical and chemotaxonomic characteristics between strain $\mathrm{H} 25^{\mathrm{T}}$ and the type strains of related species are given in Table 1 and Supplementary Tables S1-S3. Strain H25 could be distinguished from the two closest type strains, $N$. naphthalenivorans DSM $18518^{\mathrm{T}}$ and $N$. pentaromativorans US6- $1^{\mathrm{T}}$, in oxidase activity, colony colour, aesculin hydrolysis and some results from API and antibiotic susceptibility tests. On the basis of morphological, physiological and chemotaxonomic characteristics, together with data from $16 \mathrm{~S}$ rRNA gene sequence analysis and DNA-DNA hybridization, strain $\mathrm{H}_{2} 5^{\mathrm{T}}$ should be placed in a novel species, for which the name Novosphingobium indicum sp. nov. is proposed.

\section{Description of Novosphingobium indicum sp. nov.}

Novosphingobium indicum (in'di.cum. L. neut. adj. indicum Indian, referring to the Indian Ocean, where the type strain was isolated).

Cells are non-motile rods without polar flagella, 1.1$1.4 \mu \mathrm{m}$ long and $0.6-0.7 \mu \mathrm{m}$ wide. Positive for catalase, gelatinase and utilization of D-glucose, D-mannose and maltose using API 20NE, but negative for Gram-staining, oxidase, lipase (Tween 80 hydrolysis), urease, aesculin hydrolysis, $\beta$-glucosidase, $\beta$-galactosidase, arginine dihydrolase, indole production and utilization of adipic acid, $\mathrm{N}$-acetylglucosamine, capric acid, D-mannitol, L-arabinose, malic acid, phenylacetic acid, potassium gluconate and trisodium citrate. In API ZYM tests, positive for acid and alkaline phosphatases, esterase (C4), esterase lipase (C8), leucine aminopeptidase, naphthol-AS-BI-phosphoamidase, valine aminopeptidase and $\alpha$-chymotrypsin, weakly positive for cystine aminopeptidase, lipase (C14) and $\alpha$ glucosidase and negative for $N$-acetyl- $\beta$-glucosaminidase, trypsin, $\alpha$-fucosidase, $\alpha$-galactosidase, $\alpha$-mannosidase, $\beta$ galactosidase, $\beta$-glucosidase and $\beta$-glucuronidase. Growth occurs at $10-41{ }^{\circ} \mathrm{C}$ (optimum $25-30{ }^{\circ} \mathrm{C}$ ), but not at 4 or $45{ }^{\circ} \mathrm{C}$. Acid is not produced from D-glucose. Able to reduce nitrate to nitrite, but incapable of denitrification. On 216L agar plates, produces smooth, round, yellow colonies with regular edges, slightly raised in the centre, $1-2 \mathrm{~mm}$ in diameter after $72 \mathrm{~h}$ incubation at $28{ }^{\circ} \mathrm{C}$. Principal fatty acids are $\mathrm{C}_{18: 1} \omega 7 c, \mathrm{C}_{16: 0}, \mathrm{C}_{18: 0}, \mathrm{C}_{16: 1} \omega 7 c$ and $\mathrm{C}_{14: 0} 2-\mathrm{OH}$. Of 95 substrates in the Biolog GN2 system, positive for utilization of $\alpha$-cyclodextrin, dextrin, glycogen, $\alpha$-D-glucose, $\alpha$-ketovaleric acid, D-mannose, succinamic acid, Lalaninamide, L-alanine, L-alanyl glycine, L-glutamic acid, glycyl L-glutamic acid, L-leucine, L-proline, Tweens 40 and 80 , maltose, methyl pyruvate and $\beta$-hydroxybutyric acid. Sensitive to (per disc) ampicillin $(10 \mu \mathrm{g})$, carbenicillin $(100 \mu \mathrm{g})$, cefazolin $(30 \mu \mathrm{g})$, cefobid $(30 \mu \mathrm{g})$, cephradin $(30 \mu \mathrm{g})$, chloromycetin $(30 \mu \mathrm{g})$, ciprofloxacin $(5 \mu \mathrm{g})$, cotrimoxazole $(25 \mu \mathrm{g})$, erythromycin $(15 \mu \mathrm{g})$, rifampicin $(5 \mu \mathrm{g})$, gentamicin $(10 \mu \mathrm{g})$, kanamycin $(30 \mu \mathrm{g})$, minomycin $(30 \mu \mathrm{g})$, neomycin $(10 \mu \mathrm{g})$, ofloxacin $(5 \mu \mathrm{g})$, penicillin $\mathrm{G}(10 \mu \mathrm{g})$, piperacillin $(100 \mu \mathrm{g})$, rocephin $(30 \mu \mathrm{g})$, tetracycline $(30 \mu \mathrm{g})$ and vancomycin $(30 \mu \mathrm{g})$; resistant to cefalexin $(30 \mu \mathrm{g})$, clindamycin $(2 \mu \mathrm{g})$, furazolidone $(15 \mu \mathrm{g})$, lincomycin $(2 \mu \mathrm{g})$, metronidazole $(5 \mu \mathrm{g})$, norfloxacin $(10 \mu \mathrm{g})$, oxacillin $(1 \mu \mathrm{g})$, polymyxin $\mathrm{B}(30 \mathrm{U})$, streptomycin $(10 \mu \mathrm{g})$ and vibramycin $(30 \mu \mathrm{g})$. The $\mathrm{G}+\mathrm{C}$ content of the DNA of the type strain is $62 \mathrm{~mol} \%$. The major respiratory quinone is ubiquinone 10 and the major polyamine is spermidine. Table 1 shows characteristics used to distinguish the type strain from type strains of related species.

The type strain, $\mathrm{H} 25^{\mathrm{T}}\left(=\mathrm{MCCC} 1 \mathrm{~A} 01080^{\mathrm{T}}=\mathrm{CGMCC}\right.$ $1.6784^{\mathrm{T}}=\mathrm{LMG} 24713^{\mathrm{T}}$ ), was isolated from deep-sea water in December 2005.

\section{Acknowledgements}

This work was supported financially by the National Natural Science Foundation of China (40376041), the National Infrastructure of Natural Resources for Science and Technology Program of China (no. 2005DKA21209), the COMRA program (no. DYXM115-02-2-05) and the National Basic Research Program of China (nos 2004CB719601, 2006CB708200). J.Y. is a PhD student of Xiamen University cosupervised by T.Z. and Z.S.; all work was carried out at the Third Institute of Oceanography, State Oceanic Administration. 


\section{References}

Addison, S. L., Foote, S. M., Reid, N. M. \& Lloyd-Jones, G. (2007). Novosphingobium nitrogenifigens sp. nov., a polyhydroxyalkanoateaccumulating diazotroph isolated from a New Zealand pulp and paper wastewater. Int J Syst Evol Microbiol 57, 2467-2471.

Alemayehu, D., Gordon, L. M., O'Mahony, M. M., O'Leary, N. D. \& Dobson, A. D. W. (2004). Cloning and functional analysis by gene disruption of a novel gene involved in indigo production and fluoranthene metabolism in Pseudomonas alcaligenes PA-10. FEMS Microbiol Lett 239, 285-293.

Ausubel, F. M., Brent, R., Kingston, R. E., Moore, D. D., Seidman, J. G., Smith, J. A. \& Struhl, K. (editors) (1995). Short Protocols in Molecular Biology: a Compendium of Methods from Current Protocols in Molecular Biology, 3rd edn. New York: Wiley.

Balkwill, D. L., Drake, G. R., Reeves, R. H., Fredrickson, J. K., White, D. C., Ringelberg, D. B., Chandler, D. P., Romine, M. F., Kennedy, D. W. \& Spadoni, C. M. (1997). Taxonomic study of aromaticdegrading bacteria from deep-terrestrial-subsurface sediments and description of Sphingomonas aromaticivorans sp. nov., Sphingomonas subterranea sp. nov. and Sphingomonas stygia sp. nov. Int J Syst Bacteriol 47, 191-201.

Busse, H.-J. \& Auling, G. (1988). Polyamine pattern as a chemotaxonomic marker within the Proteobacteria. Syst Appl Microbiol 11, $1-8$.

Busse, H.-J., Bunka, S., Hensel, A. \& Lubitz, W. (1997). Discrimination of members of the family Pasteurellaceae based on polyamine patterns. Int J Syst Bacteriol 47, 698-708.

Collins, M. D. (1985). Isoprenoid quinone analysis in classification and identification. In Chemical Methods in Bacterial Systematics, pp. 267-287. Edited by M. Goodfellow \& D. E. Minnikin. London: Academic Press.

Cui, Z. S. \& Shao, Z. Z. (2006). Characterization of a PAHs degrading marine strain Novosphingobium sp. Phe-8 and its degradative genes. J Xiamen Univ 45, 257-261 (in Chinese).

Cui, Z., Lai, Q., Dong, C. \& Shao, Z. (2008). Biodiversity of polycyclic aromatic hydrocarbon-degrading bacteria from deep sea sediments of the Middle Atlantic Ridge. Environ Microbiol 10, 2138-2149.

Dong, X.-Z. \& Cai, M.-Y. (2001). Determinative Manual for Routine Bacteriology. Beijing: Scientific Press (English translation).

Edwards, N. T. (1983). Polycyclic aromatic hydrocarbons (PAH's) in the terrestrial environment - a review. J Environ Qual 12, 427-441.

Harvey, R. G. (1991). Polycyclic Aromatic Hydrocarbons: Chemistry and Carcinogenicity. New York: Cambridge University Press.

Lim, Y. W., Moon, E. Y. \& Chun, J. (2007). Reclassification of Flavobacterium resinovorum Delaporte and Daste 1956 as Novosphingobium resinovorum comb. nov., with Novosphingobium subarcticum (Nohynek et al. 1996) Takeuchi et al. 2001 as a later heterotypic synonym. Int J Syst Evol Microbiol 57, 1906-1908.

Liu, C. L. \& Shao, Z. Z. (2005). Alcanivorax dieselolei sp. nov., a novel alkane-degrading bacterium isolated from sea water and deep-sea sediment. Int J Syst Evol Microbiol 55, 1181-1186.

Liu, Z.-P., Wang, B.-J., Liu, Y.-H. \& Liu, S.-J. (2005). Novosphingobium taihuense sp. nov., a novel aromatic-compound-degrading bacterium isolated from Taihu Lake, China. Int J Syst Evol Microbiol 55, 12291232.

Mesbah, M. \& Whitman, W. B. (1989). Measurement of deoxyguanosine/thymidine ratios in complex mixtures by high-performance liquid chromatography for determination of the mole percentage guanine + cytosine of DNA. J Chromatogr 479, 297-306.
Mrozik, A., Seget, Z. P. \& Labuzek, S. (2004). Changes in whole cellderived fatty acids induced by naphthalene in bacteria from genus Pseudomonas. Microbiol Res 159, 87-95.

Nohynek, L. J., Nurmiaho-Lassila, E.-L., Suhonen, E. L., Busse, H.-J., Mohammadi, M., Hantula, J., Rainey, F. \& Salkinoja-Salonen, M. S. (1996). Description of chlorophenol-degrading Pseudomonas sp. strains $\mathrm{KF}^{\mathrm{T}}$, KF3, and NKF1 as a new species of the genus Sphingomonas, Sphingomonas subarctica sp. nov. Int J Syst Bacteriol 46, 1042-1055.

Rzhetsky, A. \& Nei, M. (1992). A simple method for estimating and testing minimum-evolution trees. Mol Biol Evol 9, 945-967.

Rzhetsky, A. \& Nei, M. (1993). Theoretical foundation of the minimum-evolution method of phylogenetic inference. Mol Biol Evol 10, 1073-1095.

Saitou, N. \& Nei, M. (1987). The neighbor-joining method: a new method for reconstructing phylogenetic trees. Mol Biol Evol 4, 406425.

Shieh, W. Y., Chen, Y.-W., Chaw, S.-M. \& Chiu, H.-H. (2003). Vibrio ruber sp. nov., a red, facultatively anaerobic, marine bacterium isolated from sea water. Int J Syst Evol Microbiol 53, 479-484.

Sohn, J. H., Kwon, K. K., Kang, J.-H., Jung, H.-B. \& Kim, S.-J. (2004). Novosphingobium pentaromativorans sp. nov., a high-molecular-mass polycyclic aromatic hydrocarbon-degrading bacterium isolated from estuarine sediment. Int J Syst Evol Microbiol 54, 1483-1487.

Stackebrandt, E. \& Goebel, B. M. (1994). Taxonomic note: a place for DNA-DNA reassociation and $16 \mathrm{~S}$ rRNA sequence analysis in the present species definition in bacteriology. Int J Syst Bacteriol 44, 846849.

Suess, M. J. (1976). The environmental load and cycle of polycyclic aromatic hydrocarbons. Sci Total Environ 6, 239-250.

Suzuki, S. \& Hiraishi, A. (2007). Novosphingobium naphthalenivorans sp. nov., a naphthalene-degrading bacterium isolated from polychlorinated-dioxin-contaminated environments. J Gen Appl Microbiol 53, 221-228.

Takeuchi, M., Hamana, K. \& Hiraishi, A. (2001). Proposal of the genus Sphingomonas sensu stricto and three new genera, Sphingobium, Novosphingobium and Sphingopyxis, on the basis of phylogenetic and chemotaxonomic analyses. Int J Syst Evol Microbiol 51, 14051417.

Tiirola, M. A., Busse, H.-J., Kämpfer, P. \& Männistö, M. (2005). Novosphingobium lentum sp. nov., a psychrotolerant bacterium from a polychlorophenol bioremediation process. Int J Syst Evol Microbiol 55, 583-588.

Versalovic, J., Koeuth, T. \& Lupski, J. R. (1991). Distribution of repetitive DNA sequences in eubacteria and application to fingerprinting of bacterial genomes. Nucleic Acids Res 19, 6823-6831.

Wang, B., Lai, Q., Cui, Z., Tan, T. \& Shao, Z. (2008). A pyrenedegrading consortium from deep-sea sediment of the west Pacific and its key member Cycloclasticus sp. P1. Environ Microbiol 10, 1948-1963.

Wayne, L. G., Brenner, D. J., Colwell, R. R., Grimont, P. A. D., Kandler, O., Krichevsky, M. I., Moore, L. H., Moore, W. E. C., Murray, R. G. E. \& other authors (1987). International Committee on Systematic Bacteriology. Report of the ad hoc committee on reconciliation of approaches to bacterial systematics. Int J Syst Bacteriol 37, 463-464.

Yuan, J., Lai, Q., Zheng, T. \& Shao, Z. (2008). Polycyclic aromatic hydrocarbon-degrading bacterium Novosphingobium sp. H25 isolated from deep sea and its degrading genes. Acta Microbiol Sin 48, 1-6 (in Chinese). 